\section{A REVIEW OF THE USE OF RECLAIMED ASPHALT PAVEMENT FOR ROAD PAVING APPLICATIONS}

\author{
Abdalrhman Milada, Aizat Mohd Taiba*, Abobaker G. F Ahmedab, \\ Mohmed Sollac, Nur Izzi Md Yusoffa \\ aDept. of Civil and Structural Engineering, Universiti Kebangsaan \\ Malaysia, Selangor, Malaysia \\ bDept of Civil and Structural Engineering, Higher Institute of \\ Science and Technology Aljufra (HIST), Sokna, Libya \\ cDept. of Building and Construction Engineering, Universiti Tun \\ Hussein Onn Malaysia, Parit Raja, Johor, Malaysia
}

Article history

Received

15 October 2019

Received in revised form

19 February 2020

Accepted

4 March 2020

Published online

23 April 2020

*Corresponding author amohdtaib@ukm.edu.my
Graphical abstract

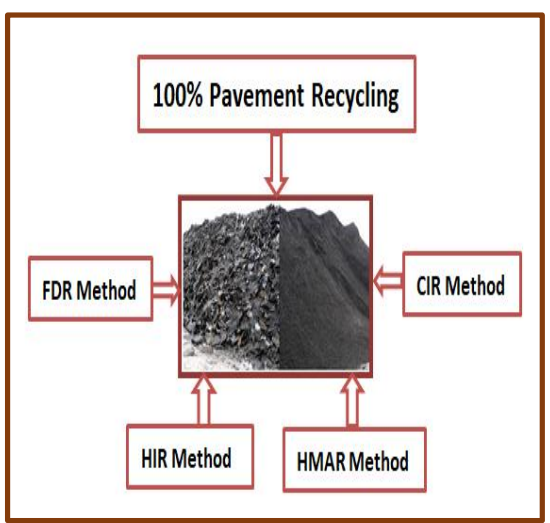

\begin{abstract}
One of the most frequently used waste materials is reclaimed asphalt pavement (RAP). The use of RAP can help reduce the cost of a project and ensure that the project is eco-friendly. Therefore, the aim of this study is to give a detailed description of the production of RAP to ensure that the rehabilitation and maintenance of pavements as well as the construction of pavements are environmentally friendly and cost effective. Previous works have shown the benefits of using RAP with regard to its ability to produce equally good or even superior results compared to the use of virgin or original mixes if they are properly produced and applied. Among the benefits of RAP mixes are good moisture resistance and higher density. This review also demonstrate the critical importance of using RAP in asphalt mixtures.
\end{abstract}

Keywords: Moisture resistance, asphalt pavement recycling, reclaimed asphalt, RAP

\begin{abstract}
Abstrak
Salah satu bahan buangan yang paling sering digunakan ialah turapan asfalt terpulih guna (RAP). Penggunaan RAP dapat mengurangkan kos projek dan memastikan projek itu adalah endah alam sekitar. Oleh itu, tujuan kajian ini adalah untuk menghuraikan secara terperinci pengeluaran RAP untuk memastikan yang pemuliharaan dan penyelengaraan serta pembinaan turapan adalah mesra alam sekitar dan berkesan kos. Hasil kajian terdahulu menunjukkan bahawa antara manfaat penggunaan RAP adalah hasil yang setaraf atau lebih baik daripada campuran dara atau campuran asal sekiranya ia dihasilkan dan digunakan dengan menurut kaedah yang betul. Antara manfaat campuran RAP adalah rintangan lembapan yang baik dan ketumpatan lebih tinggi. Kajian ini juga akan menunjukkan kepentingan menggunakan RAP dalam campuran asfalt.
\end{abstract}

Kata kunci: Rintangan lembapan, kitar semula turapan asfalt, asfalt terpulih guna, RAP (c) 2020 Penerbit UTM Press. All rights reserved

\subsection{INTRODUCTION}

At present, recycled materials are frequently used in the base layers of asphalt pavements. This method is used for the shoulder of rural and urban road pavements via cold or hot-in place recycling. It involves the addition of a very small amount of additive material to the asphalts [1]. According to the Federal Highway Administration (FHWA) up to 100 million tons of hot-mix asphalt are milled annually[2]. The primary reason for using RAP is to eliminate the need to use aggregates and asphalt in 
the existing pavements [3]. The materials are categorized after the removal of asphalt pavements for rehabilitation and maintenance. RAP consists of high-quality, well-graded aggregates coated with asphalt cement with high moisture content [2].

The properties of RAP makes it an excellent substitute for virgin resources and thus is able to reduce the need to use virgin aggregates. This makes RAP an eco-friendly and cost-effective alternative for virgin aggregates. The use of RAP also help to reduce the amount of overpriced new asphalt binders used in asphalt paving mixtures [4]. The three primary advantages of using reclaimed asphalt pavements are its eco-friendliness, costeffectiveness and good performance. Due to these benefits, the FHWA has set the following objectives in an effort to promote the recycling of asphalt pavement:

- The use of RAP has considerable environmental benefits.

- The use of recycled materials in highway construction has economic benefits and is able to improve pavement performance.

Currently, waste materials, such as sand, ground tire rubber, and even glass are used in pavement construction. However, reclaimed asphalt pavement (RAP) is the most commonly used recycled material in pavement construction. In 2014, the National Asphalt Pavement Association (NAPA) reported that about 71.9 million tons RAP was used in the construction of new pavements in the United States. This means that RAP actually save American taxpayers around USD 2.5 billion each year [5]. Moreover, in 2018, more than 100 million tons of RAP was collected for reuse in the United States, thereby saving about 61.4 million cubic yards of landfill space [6]. The cost effectiveness and eco-friendliness of recycled materials, including RAP, have made their use an attractive choice in some parts of the world [7].

\subsection{ASPHALT PAVEMENT WASTE PROBLEM}

Any material produced by manufacturers or individuals that lack any residual value is termed as waste [8]. State highway agencies agreed that the technical feasibility of these materials ranges from very good to satisfactory and that the materials are acceptable in terms of eco-friendliness and are economically feasible because of their costcompetitiveness compared to the use of virgin materials. The objective of this investigation is to shed light on certain issues with regard to RAP [9]. It will also summarize the material's potential benefits. The materials investigated in this study are rubber from car tires, asphalt roofing shingles, and steel. These materials are used in other industries and are usually recycled into asphalt pavements instead of being disposed of in landfills. Asphalt plants reuse the fine mineral particles that are formed in the process of creating asphalt pavement material. This type of repetitive recycling of co-generated material could help to conserve natural resources. This study aims to: (i) assess waste management in construction; (ii) assess the importance of recycling materials; and (iii) assess the viable technologies for ten construction waste materials, namely (1) concrete, (2) asphalt, (3) glass, (4) brick, (5) masonry, (6) ferrous metal, (7) paper and cardboard, (8) non-ferrous metal, (9) plastic, and (10) timber. Serpell and Alarcon [8] defined construction wastes as the materials produced by industrial and human activities that lacks any residual value. All construction companies should be required to have a management plan for construction wastes that is tailored to suit their specific business. This ensures that all employees of the company work towards achieving the same aim in the management of construction wastes. In addition to reducing the production of wastes, other important economic issues in construction waste management are related to recycling and contractual impacts [10].

\subsection{HISTORY OF RAP}

RAP has been used in asphalt mixes since 1915 and this is especially important for environmental and economic reasons [11]. The introduction of the Superpave system provides a foundation for the development of RAP in an effort to enhance the Superpave guidelines. The use of reclaimed asphalt pavement (RAP) was particularly attractive during the 1970s, especially with the rising oil price during the Arab oil restriction. As a consequence asphaltpaving technologists were forced to develop recycling methods that are able reduce the demand for asphalt binder, thereby reducing the cost of asphalt paving mixtures. Most of the methods developed during this period are still being used today, especially for routine pavement rehabilitation and construction. During the late 1990s, the American State Transportation Departments used RAP for several years prior to using the Superpave mixture design method [4].

The Department of Transportation (DOT) typically use the maximum quantity of RAP in surface layers, particularly for government projects. Despite the fact that a small number of HMA still use RAP, the amount never exceed $15 \%$. However, the increase in the cost of asphalt binder as well as the shortage in the supply of aggregates in 2006 and 2013 has resulted in the production of greater quantities of RAP and this has become a major issue in the HMA industry [12]. For more than 30 years the two core principles of reclaimed asphalt are: 
- The requirements for RAP mixtures should be similar to those for mixes containing all virgin materials.

- $\quad$ The performance of mixtures containing RAP should be similar to or exceed those of virgin mixtures.

In the United States the average RAP content in new asphalt mixes range between 12 and $15 \%$. The National Asphalt Pavement Association (NAPA) aimed to increase the average RAP content to $25 \%$ by the end of 2013. For ten years, there was successful planning and production of recycled quality mixtures of RAP. Recent studies conducted in the United States and in Canadian provinces have proven that the performance of mixes containing a minimum of $30 \%$ RAP is similar to those containing virgin materials [13].

\subsection{CHARACTERIZATION OF RAP}

All roads constructed using HMA have an age limit. As the pavements approach the end of their life cycle, the value of milled material remains unaffected. In attempting to reduce the amount of new materials used in pavements, milled material known as RAP can be reused. Various rheological and physical variables must be considered for the combination of binders and aggregates during the time when there is no operation. This consideration, especially during the design process, ensures that the performance of HMA containing RAP is similar to that of HMA mixes containing virgin materials.

Numerous laboratory tests have been carried out in Oman to establish the physical properties of RAP and virgin aggregates. Among the tests carried out are Atterberg limit, specific gravity, toughness, moisture content, gradation, sand equivalence, water immersion, and moisture content tests. However, a maximum of only $10 \%$ RAP is allowed in the construction of road infrastructures. Stabilized RAP material has to be compared to the traditional sub-base materials used in Oman. In general, higher virgin aggregate content leads to higher California Bearing Ratio (CBR) and dry density values [14]

The use of RAP has the potential to improve the benefit-cost ratio and life-span of road pavements [15]. The preservation programs only involve preservation activities that have a benefit-cost ratio greater than 0.25. It is best to fill cracks as soon as the first sign of crack is observed even though the filling of cracks was found to be beneficial for SR having a pre-treatment PSI exceeding 2.5. This is because prompt treatment helps to prevent continuous pavement degeneration [16].

Several investigations have highlighted that there is no change in the performance of the mixes incorporated with a certain percentage of RAP [[17]. Other studies have highlighted the fact that the addition of RAP increased the stiffness of a mix [18].
Temperature has been shown to affect fatigue life [18]. The tensile strength is similar to or higher than that of virgin mixes $[17,18]$. In the construction of highways, large quantities of RAP is removed by mixing it into sub-stem and floor applications. In Illinois, RAP materials may contain general aggregates which include steel slag that is not legally allowed for use in the substructure layer of pavements [19]. Despite the fact that steel slag aggregates play an important role in areas where high frictional properties are required, such as in HMA surface courses, the presence of lime and magnesia in steel slag aggregates may cause them to swell upon contact with water. It was found that recycled mixes have better moisture damage resistance at low RAP percentages. The properties of seventeen virgin aggregates and RAP materials were assessed using ASTM D4792 "Potential Expansion of Aggregates from Hydration Reactions" in an investigational approach. This approach used high alkali cement, where the specimens were soaked in water with a $\mathrm{pH}$ of 12 in the California Bearing Ratio (CBR) test moulds. In order to hasten the hydration process, the test moulds were soaked at $70^{\circ} \mathrm{C}$. Continuous measurement of the solution's $\mathrm{pH}$, temperature and CBR specimens' progress percentage were made throughout the minimum soaking period of 7 days and maximum soaking period of 60 days until a flattened growth curve was achieved [19].

A study has been carried out on a bio-modified binder to determine the ability of bio-modification to integrate high percentages of RAP. The effect of the bio-modified binder on the stiffness and workability of the control mixture in the presence and absence of RAP was measured by determining the mixtures' properties, including torque resistance and dynamic modulus [15]. Results indicated that the bio-modified binder was able to reduce the stiffness of the control mixture containing $40 \%$ RAP to a degree closer to the stiffness of a similar mixture without RAP. The incorporation of bio-binder also enhanced the workability of the mixture, especially at high RAP content of $40 \%$. This indicates that cracking properties and weariness, or fatigue, can be improved by the addition of bio-modifier binder. In addition, the bio-modified binder did not have any adverse effect on moisture susceptibility and rutting properties of the control mixture containing 40\% RAP. Generally, the results of this study demonstrated an acceptable combination of virgin/bio-modified and RAB binders [20].

\subsection{BENEFITS OF RAP}

Asphalt pavements that have reached the end of their life cycle can be removed, reused, and landfilled, or remain in the area where they were originally used to be reused as a backing structure for new pavings. If the asphalt pavement is recycled 
as it approaches the end of its life cycle, it will be milled to obtain a perfectly reusable reclaimed asphalt pavement (RAP). RAP can be used in new asphalt mixtures. The use of RAP as aggregate replacement for road base layers have shown that the full use of RAP brings considerable economic savings and environmental and engineering benefits [21].

\subsection{Economic Benefits}

According to Babashamsi et al. 2006 the life cycle cost analysis of pavements incorporated with RAP showed that a saving of $\$ 58,000 / \mathrm{km}$ can be achieved for asphalt mixtures containing 30 to $50 \%$ RAP. This saving consists of the savings in material cost due to the replacement of a part of the binders' virgin aggregates with RAP and the lower transportation cost. Conventional crushed stones are generally more expensive than recycled materials. According to Edil [22] a saving of up to $30 \%$ was achieved by using RAP as base material for pavements. The most expensive component of asphalt pavement construction is the asphalt binder. The use of RAP material in pavement construction means that less asphalt binder is required. As such, it has been proposed that the most economical use of RAP in asphalt mixtures is in the immediate and surface layers of flexible pavements [22].

\subsection{Environmental Benefits}

Amongst the many environmental benefits of using RAP are reduced demand for non-renewable resources; less landfill space is required for the disposal of used pavements; reduced fuel consumption and emissions since the materials do not have to be transported; and less extraction of virgin materials [24]. Previous studies have proven these benefits. For instance, one study has shown that the incorporation of $15 \%$ RAP into warm-mix asphalt mixtures was able to reduce the total cumulative energy requirement, climate change and use of fossil fuels by 13 to $14 \%$ [23].

\subsection{Engineering Benefits}

A survey was carried out in the United States to compare the Long-Term Pavement Performance of virgin mixes and mixes containing RAP. Results show that, in terms of all aspects of pavement performance, the performance of mixes containing a minimum of $30 \%$ RAP is equivalent to those containing virgin materials. Another study has shown that the base layers containing RAP have higher strength than those containing conventional aggregates. The use of RAP has also been demonstrated to be suitable for the construction of pavements in areas with low traffic and freezing temperatures; areas with high traffic and nonfreezing temperatures; and areas with medium traffic and freezing temperatures as well as low moisture levels [24].

\subsection{EFFECT OF RAP}

The use of RAP has become increasingly popular in the asphalt industry and many studies have been conducted on this subject. However, the results of these studies are not as anticipated in that the use of RAP is still very limited, and that RAP has an unfavorable reputation among the pavement community, especially with regard to the use of RAP materials in new asphalt mixes. The incorporation of RAP in HMA resulted in a shorter fatigue life [25]. Additionally, higher percentages of RAP resulted in reduced racking resistance of HMA-RAP mixtures' [26]. The explanation for the findings of the two studies is related to the stiffening effect of the aged RAP binder on the blended virgin-RAP binder within the mixture. Previous studies have shown that higher RAP content increases permeability and resilient modulus whilst reducing shear strength. RAP materials exhibited a more pronounced pavement degeneration and resilient modulus. Another study found that higher percentages of RAP have the effect of reducing shear strength [27]. Unlike virgin aggregates, RAP can reduce a material's bearing capacity. Increasing the amount of RAP resulted in greater permanent degeneration and smaller CBR value. Thus, it is recommended for the RAP to be mixed with virgin aggregates and that the weight of RAP should not exceed $50 \%$ [28]. WMA-high RAP mixtures have reduced rutting and moisture resistance compared to HMA-high RAP mixtures [29]. Regardless of the pavement layer and WMA technology employed, high RAP- WMA mixtures exhibit better fatigue resistance than high RAP-WMA mixtures. Hence, rutting may still be a concern for high RAP-WMA mixtures while fatigue may not present any problem. In addition, with the exception of foamed base WMA mixtures, high RAP-WMA mixtures have an acceptable resistance to moisture. Despite the benefits of asphalt recycling and reclamation as a rehabilitation technique, not all reclamation and pavement and asphalt recycling are suitable for the treatment of different forms of pavement distress. Considering that there are differences between by-products in terms of their properties and form, RAP should be used based on the following principles: 1) mixtures with RAP should be able to meet the requirements set for mixes with virgin materials, and 2) the performance of mixes containing RAP should be equivalent to or exceed the performance of virgin asphalt mixtures [30]. 


\subsection{REHABILITATION AND MAINTENANCE USING ASPHALT RECYCLING}

Several sustainable pavement rehabilitation methods have been used across the globe to extend the life of pavements and highways. Certain rehabilitation methods are able to prolong pavement life if carried out on a regular basis. These include CIR, FDR, HIR, and HMAR. The most frequently used in-place recycling specifications are presented in Table 1 [54].

Table 1 Specifications for In-Place Recycling [54]

\begin{tabular}{|c|c|c|c|}
\hline Specification & HIR & CIR & FDR \\
\hline Method & Often & Oftenb & Frequently \\
\hline End result & Sometimesa & Sometimes & Frequently \\
\hline Performance & Sometimesa & Sometimesa & Oftena \\
\hline Warranty & Sometimesa & Sometimes & Oftena \\
\hline
\end{tabular}

The experience in asphalt material recycling differs substantially among highway agencies throughout the world [31]. The Asphalt Recycling and Reclaiming Association lists four recycling methods: (1) full-depth reclamation; (2) hot mix asphalt recycling; (3) hot in-place recycling; and (4) cold in-place recycling. Each particular pavement problem is addressed using a particular recycling approach. Moreover, the recycling techniques used for pavement preservation or corrective maintenance takes into account the time of maintenance. Figure 1 presents the pavement condition index against time that are used to formulate asphalt recycling and reclaiming strategies [32].

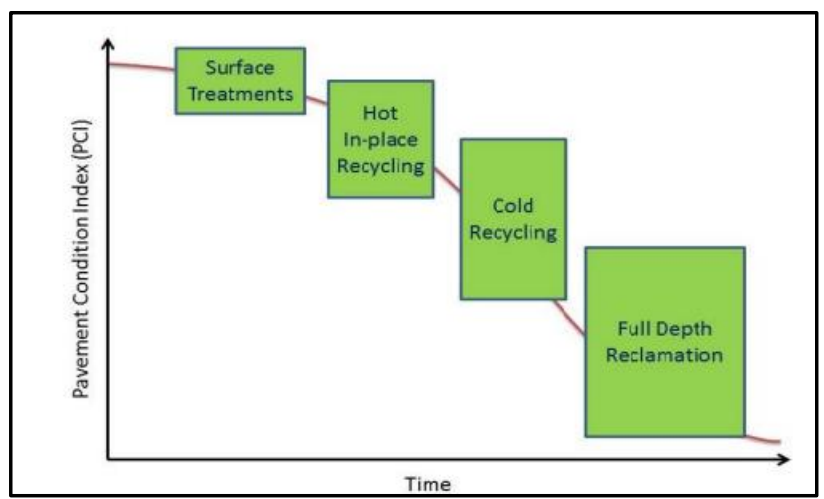

Figure 1 Asphalt recycling and reclaiming strategies for different pavement condition index [32]

Apart from the availability of experienced contractors, among the engineering factors for choosing a particular method are pavement distress and structural strength, availability of the required equipment, costs of long-term maintenance, initial price, and construction's effect on traffic flow. A detailed explanation of each method is provided along with the purpose of treatment, applicability, traffic, climate, condition addressed, considerations and expected performance life [33-35]. Several characteristics of the selected methods are summarised in Table 2, and a detailed description is given in the following sub-sections.

Table 2 Asphalt pavement maintenance and rehabilitation using RAP

\begin{tabular}{|c|c|c|c|c|}
\hline \multirow{2}{*}{$\begin{array}{l}\text { Application } \\
\text { Technique }\end{array}$} & \multicolumn{4}{|c|}{ Evaluation factor } \\
\hline & Climate & Traffic & $\begin{array}{l}\text { Condition } \\
\text { Addressed }\end{array}$ & Contraindication \\
\hline $\begin{array}{l}\text { Cold In-Place } \\
\text { Recycling (CIPR) }\end{array}$ & $\begin{array}{l}\text { Remediation } \\
\text { well in all werforms } \\
\text { conditions }\end{array}$ & $\begin{array}{l}\text { Very successful in both } \\
\text { high- and low-volume } \\
\text { roadways }\end{array}$ & $\begin{array}{l}\text { Reconstruction of } \\
\text { old pavements }\end{array}$ & $\begin{array}{l}\text { - Long remaining life, } \\
\text { - Extend the service life of } \\
\text { roadway pavements by 10-15 } \\
\text { years }\end{array}$ \\
\hline $\begin{array}{l}\text { Hot mix asphalt } \\
\text { recycling (HMAR) }\end{array}$ & $\begin{array}{l}\text { Dried treatment } \\
\text { sealants perform better } \\
\text { in warmer climates }\end{array}$ & $\begin{array}{l}\text { Performance is not } \\
\text { significantly affected } \\
\text { by different ADT or } \\
\text { truck levels }\end{array}$ & $\begin{array}{l}\text { Reconstruction of } \\
\text { old pavements }\end{array}$ & $\begin{array}{l}\text { - Extend service life of roads for } \\
\text { over } 12 \text { years }\end{array}$ \\
\hline $\begin{array}{l}\text { Hot in-place } \\
\text { recycling (HIR)) }\end{array}$ & $\begin{array}{l}\text { Dried treatment } \\
\text { sealants perform better } \\
\text { in warmer climates }\end{array}$ & $\begin{array}{l}\text { Performance is not } \\
\text { significantly affected } \\
\text { by different ADT or } \\
\text { truck levels }\end{array}$ & $\begin{array}{l}\text { Correct shallow- } \\
\text { depth HMA } \\
\text { surface distress. }\end{array}$ & $\begin{array}{l}\text { - Preservation treatment process } \\
\text { is expected to extend pavement } \\
\text { life by } 10-12 \text { years }\end{array}$ \\
\hline $\begin{array}{c}\text { Full-depth } \\
\text { reclamation (FDR) }\end{array}$ & $\begin{array}{l}\text { Remediation performs } \\
\text { well in all climate } \\
\text { conditions }\end{array}$ & $\begin{array}{l}\text { Higher traffic bearing } \\
\text { capacity }\end{array}$ & $\begin{array}{l}\text { Stabilized base } \\
\text { course }\end{array}$ & $\begin{array}{l}\text { - Extend the service life of } \\
\text { roadway pavements by } 10 \text { years }\end{array}$ \\
\hline
\end{tabular}




\subsection{Hot Mix Asphalt Recycling (HMAR)}

In HMAR, new materials are mixed with reclaimed asphalt pavement (RAP) materials to produce hot mix asphalt (HMA). A recycling agent is used in some mixtures. This method requires the use of RAP materials that are collected via milling or ripping and crushing operations. In hot mix asphalt recycling, the mix placement and compaction equipment and the steps are similar to the usual HMA. Hot mix asphalt recycling mixtures typically require the incorporation of $10-30 \%$ of RAP materials. In addition to being able to deal with most surface deformation, cracking and defects, the performance of the mixtures produced using this technique is equivalent to or even better than conventional HMA [36].

\subsection{Hot in-Place Recycling (HIR)}

HIR involves heating, softening and milling the existing pavement to a particular depth, as shown in Figure 3. In HIR the placement of the new HIR mix, compaction equipment, and procedures are similar to those of regular HMA technique. HIR may be carried out either as a multiple pass or single-pass operation. In the single-notch process, the new materials may be incorporated with the required chamfered in-place materials. The thickness of the materials varies from 20 to $50 \mathrm{~mm}$. Three methods may be used in the HIR method: (1) remixing, (2) surface recycling, and (3) re-paving. Among the benefits of hot in-place recycling are correction of rutting, shoves and bumps; modification of aggregate gradation and asphalt content; elimination of surface cracks; lower hauling costs; and minimal traffic interruption [37].

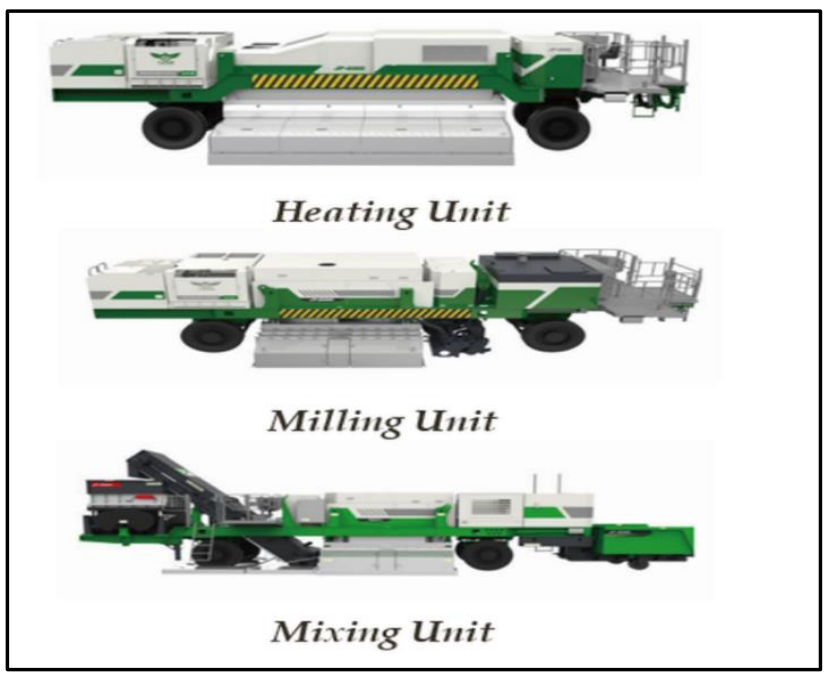

Figure 3 The machines used for hot in place recycling [38]

\subsection{Cold In-place Recycling (CIR)}

In this method, the reuse of current pavement material does not require heat application, as shown in Figure 2. This reduces the cost of hauling considerably since only the recycling agent has to be transported. The asphalt emulsion is commonly incorporated as a binder or a recycling agent. Thither refers to the ratio between the emulsions, which is proportioned as a percentage of total RAP. The use of Portland cement, quick-lime, fly ash additives not only delay surface raveling but also provide a curing overlay for the additive to properly set. This method consists of sizing the RAP, pulverizing the existing pavement, application of recycling agent, and placement. The depth of treatment is between 75 to $100 \mathrm{~mm}$. The benefits of cold in-place recycling include the ability to widen pavement, minimum hauling and air pollution, good structural treatment of most pavement problems and better ride quality [39].

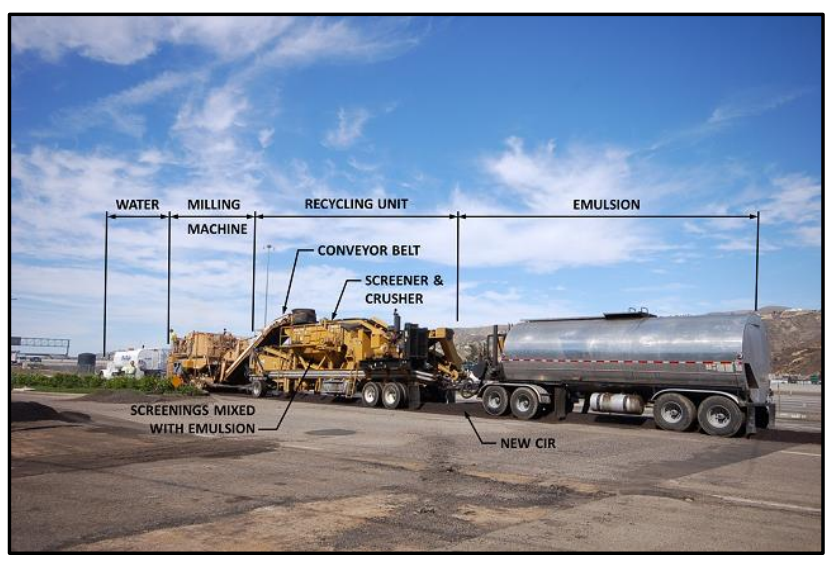

Figure 2 Cold in place recycling method [40]

\subsection{Full Depth Reclamation (FDR)}

Full Depth Reclamation (FDR) is used when the quantity of underlying base material has been determined and an entire asphalt pavement section is to be treated to form a stabilized base course. Figure 4 shows the processing of RAP material in FDR.

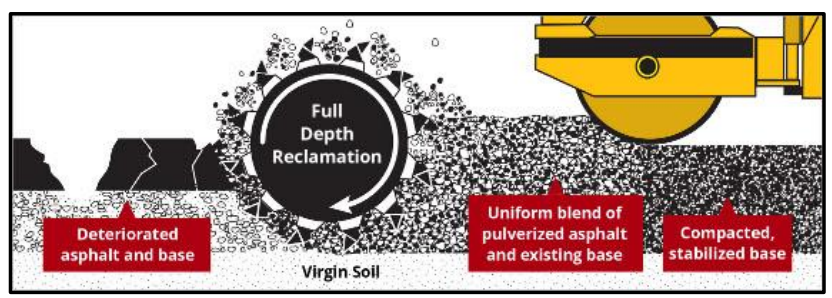

Figure 4 Full-depth reclamation process [41] 
Generally, this is a cold mix recycling step which differs from other forms of additives, including asphalt emulsion and chemical agents, calcium chloride, fly ash, lime, and Portland cement, which are added in the final stage to enhance the structure. The four major steps in this recycling method are pulverization, compaction, application of wearing or surface course, and incorporation of additive. In the case where the in-place material is not able to meet the required depth of the treated base, new materials may be used and incorporated. The in-place material is combined with a new aggregate to provide the desired depth of the treated base. The depth of this recycling method typically ranges between 100 and $300 \mathrm{~mm}$ [42].

\subsection{ADVANTAGES AND DISADVANTAGES OF COLD RECYCLING}

Generally, the term 'cold recycling' indicates lower working temperature in each process of the recycling. The three cold recycling methods are (1) full-depth reclamation; (2) cold center plant recycling, and (3) cold in-place recycling [44].

\subsection{Cold In-Place Recycling (CIR)}

The CIR method is carried out 'in-place' where all recycling processes are carried out on-site at a lower working temperature as compared to hot recycling methods. This entails less loading and hauling during the entire recycling process since all work will be carried out at the same place without having to move around [45]. Moreover, the use of CIR method reduces the time taken for pavement construction or rehabilitation and the use of non-renewable resources is significantly reduced since most of the materials used in the CIR method are recycled materials [46]. Xiao et al. compared RAP with other methods, namely Hot Mix Asphalt Recycling and Cold Center Plant Recycling. CIR was found to consume the least energy during the critical recycling processes. The cost of the CIR rehabilitation method is lower as compared to conventional methods due to the smaller amount of binder and aggregates required in this process [44]. According to Murphy and Emery [45], the use of CIR method is able to reduce the cost of milling, strengthen the granular base, and recyle the existing asphalt by $30-$ $60 \%$. A significant improvement in the pavement structure was observed subsequent to the application of the CIR method. CIR can be used to treat any type of pavement deformation [45]. CIR mixtures have to be cured for a long period of time to increase its strength. Thus, this method is not recommended for rehabilitation projects which have a time constraint. The overall CIR process is dependent on ambient temperature and moisture conditions [46]. The equipment used in this recycling process is large and requires a large space, and thus will disrupt traffic flow [47].

\subsection{Cold Center Plant Recycling (CCPR)}

Unlike CIR, the CCPR method is not used frequently as it is usually used for rehabilitating roads with lower traffic volume and when CIR may not be feasible. The first stage in the CCPR is similar to that of CIR where the existing asphalt segment is processed and the materials are gathered and stored for later use in the plant. The recycled materials are physically reduced to the required size and blended with additional substances, water, and new materials. This way, the usual asphalt wearing course will be laid on the recycling asphalt. Similar to the CIR method, CCPR has the benefits of reducing expenses, preserving the ecology, and reducing the development period [48-51].

\subsection{Full Depth Reclamation (FDR)}

The FDR process is an extension of the basic CIR principles to the entire HMA pavement depth plus a predetermined depth of the base material [52]. FDR involves the use of multi-functional recycling trains and recovering machines with depths of between $100-300 \mathrm{~mm}$ [53]. This method is particularly suitable for areas with cold and dry climate. Wet atmospheres, either hot or cold, have a greater influence on the decision to set up a recycling strategy [54]. The primary benefit of this method is the reduced cost since the processed material does not have to be transported and amassed. The amount of FDR rehabilitation work performed is related to the proactive Pavement Management System [55]. The results of Minnesota Department of Transport (MnDOT) standards indicate that, over a 35-year period, FDR may be a more cost-effective technique in comparison to the conventional factory and overlay method [56]. In addition, the use of FDR is considerably affected by environmental condition. In fact, there is reliance on an overlay with a particular thickness in order to proceed with the re-established asphalt's water consistent quality $[57,58]$.

\subsection{ADVANTAGES AND DISADVANTAGES OF RAP}

\subsection{Hot In-place Recycling (HIR)}

The use of HIR is limited to situations where the depth of pavement distress is limited to 25 to50 $\mathrm{mm}$ from the surface and when there is no major structural distress such as edge cracking, crocodile cracking, and longitudinal cracking in the wheel path. The economic and environmental advantages of using $H I R$ is well-known, including the reduced cost due to the smaller amounts of the required virgin aggregate and asphalt binder, reduced hauling of new and 
removed materials to and from site, and less traffic disruption as a result of fewer lane closures [59].

HIR and CIR are especially useful in regions with wet climate for several reasons:

- Rain may disrupt work progress. Large and moderate equipment has to be switched off and work has to be halted.

- The performance may be affected if there was rainfall before the work is completed.

However, according to Xiao et al. [44], hot mix asphalt recycling consumes the highest amount of energy compared to other recycling methods. This is due to the high working temperature of between $120^{\circ} \mathrm{C}-160^{\circ} \mathrm{C}$ required in hot mix asphalt recycling. The high temperature leads to the emission of higher amounts of greenhouse gases, and it may also affect work productivity.

\subsection{Applications of Cold Recycling}

The Virginia Department of Transportation (VDOT) implemented an important asphalt recycling initiative during the 2011 construction season, which is a co-integration of the first run through full-depth reclamation (FDR), cold central plant recycling (CCPR), and cold in-place recycling (CIR). The CCPR and CIR blends were developed using hydraulic cement and foamed asphalt and serve as stabilizing agents. Following the completion of the asphalt recovery initiative, the CCPR and CIR blends' building characteristics were determined using fieldcored examples [60].

A study was carried out to determine the feasibility of using cold recycling asphalt mixture as a foundation course for an Italian motorway. The proposed mixture was developed at a central plant using high-reclaimed asphalt (RA) substance. In particular, a unique mixing system which includes the use of bituminous emulsion and water vapor was assessed [49]. In order to achieve one of the specific goals of the 2013-2020 Spanish strategy for science, technology and innovation, which is resourceefficient, eco- and climate-friendly, as well as a comfortable and safe European transport system, the pavements must be constructed using CIR techniques [23]. The increasing awareness of environmental implications has made the CIR method one of the popular methods for constructing and rehabilitating pavements.

Continuous traffic load along the Vadodara Halol Road in India eventually caused various types of distresses such as rutting, severe crocodile cracks, and segregation of aggregates. Many rehabilitation and maintenance work have been carried out which incurred a relatively high cost. The use of CIR was then proposed in an effort to reduce rehabilitation and maintenance costs. The use of CIR method proved to be very economical [61-64]. The investigation carried out in an effort to develop a cold recycling application which uses water and multiple additives, including recycling agent, cement, emulsifying agent, and modifier has resulted in improved engineering performance [65].

\subsection{Applications of Hot Recycling}

Several investigations have been carried out at the University of Illinois at Urbana-Champaign on the suitability of using HIR as a preservation technique for local roads by considering pavement performance and environmental impacts at three test sites. The rheological and physical properties of the binder recovered from each site indicated the binder performance range between (40 and 64 ) ${ }^{\circ} \mathrm{C}$ and between (-34 and -46$){ }^{\circ} \mathrm{C}$ for high and lowtemperature, respectively [66]. A comparison was made between the $\mathrm{AC}$ with $35 \%$ reclaimed asphalt pavements (RAP) pavement section and the virgin section. The study investigated three parameters: transverse cracking, rut depth, and ride quality [67]. The use of HIR and FDR by agencies was distributed across the United States. However, there is no reported use of CIR in the southern and southeastern states. This may be because of the high humidity and temperatures in these states and the belief that CIR requires emulsified binders. More than $40 \%$ of the responding agencies and contractors did not use HIR [68-72]. Unlike other countries, in Alaska, RAP is commonly used to construct roadways and airport runways. One of the reasons RAP is widely used in Alaska is the insufficient amount of high-quality materials in the state. Hence, many agencies have decided to increase RAP content considering that many future projects would require the use of RAP [73].

\subsection{CONCLUSION}

Based on the advantages and disadvantages discussed, it is apparent that RAP methods have the advantage of minimising maintenance and rehabilitation costs as well as environmental impact since these methods used recycled asphalt pavement which contribute to reducing wastes. Previous studies have established that CIR is the most frequently used method in rehabilitation and construction work. This is because the entire recycling process takes place on-site and therefore consumes less energy, emit less greenhouse gases, and is more cost-effective compared to other methods.

Unlike hot recycling, cold recycling is more environmentally friendly and affordable as the running temperature of cold recycling is lower than that for hot recycling. With respect to the scope of application, some countries are not able to fully adopt RAP methods due to lack of knowledge and expertise. RAP is frequently used in Alaska due to the lack of high-quality natural resources in the state, thus making RAP materials the only option for maintenance and rehabilitation. 


\section{References}

[1] Zaumanis, M., Mallick, R. B. \& Frank, R. 2014. 100\% Recycled Hot Mix Asphalt: A Review and Analysis. Resources, Conservation and Recycling. 94: 230-245.

[2] Federal Highway Administration. 2008. User Guidelines for Waste and By-product Materials in Pavement Construction. Washington, DC: FHWA.

[3] Arshad, A. K., Karim, Z. A., Shaffie, E., Hashim, W., \& Rahman, Z. A. 2017. Marshall Properties and Rutting Resistance of Hot Mix Asphalt with Variable Reclaimed Asphalt Pavement (RAP) Content. Paper Presented at the IOP Conference Series: Materials Science and Engineering.

[4] Copeland, A. 2011. Reclaimed Asphalt Pavement in Asphalt Mixtures: State of the Practice. McLean, VA: Turner-Fairbank Highway Research Center, Report Number FHWA-HRT-1 1021.

[5] George, A. M., Banerjee, A., Puppala, A. J., \& Saladhi, M. 2019. Performance Evaluation of Geocell-reinforced Reclaimed Asphalt Pavement (RAP) Bases in Flexible Pavements. International Journal of Pavement Engineering. 1-11.

[6] Song, W., Huang, B., \& Shu, X. 2018. Influence of Warmmix Asphalt Technology and Rejuvenator on Performance of Asphalt Mixtures Containing 50\% Reclaimed Asphalt Pavement. Journal of Cleaner Production. 192: 191-198.

[7] Xiao, F., Su, N., Yao, S., Amirkhanian, S., \& Wang, J. 2019. Performance Grades, Environmental and Economic Investigations of Reclaimed Asphalt Pavement Materials. Journal of Cleaner Production. 211: 1299-1312.

[8] Serpell, A. and Alarcon, L. F. 1998. Construction Process Improvement Methodology for Construction Projects. International Journal of Project Management. 16(4): 215221.

[9] Sufian, Z., Aziz, A. N., \& Hussain, M. Z. 2005. Cold In-place Pavement Recycling in Malaysia. 2005 International Symposium on Pavement Recycling.

[10] Tam, V. W., \& Tam, C. M. 2008. Waste Reduction Through Incentives: A Case Study. Building Research \& Information. 36(1): 37-43.

[11] Kennedy, T. W., W. O. Tam, and M. Solaimanian. 1998. Optimizing Use of Reclaimed Asphalt Pavement with the SuperPave System. Journal of the Association of Asphalt Paving Technologists. 67: 311-333.

[12] Thakur, J. K. 2013. Geocell-reinforced Unpaved and Paved Roads with Recycled Asphalt Pavement (RAP) Bases: Experimental Study and Damage Model Development. University of Kansas.

[13] West, R. 2010. Reclaimed Asphalt Pavement Management: Best Practices. Auburn, AL: National Center for Asphalt Technology, NCAT Draft Report.

[14] Deniz, D., Tutumluer, E., \& Popovics, J. S. 2009. Expansive Characteristics of RAP Materials for Use as Aggregates in the Pavement Substructure Layers. Paper Presented at the Bearing Capacity of Roads, Railways and Airfields. 8th International Conference (BCR2A'09) University of Illinois, Urbana-Champaign.

[15] Walaa S. Mogawer, Ellie H. Fini, Alexander J. Austerman, Abbas Booshehrian \& Boubacar Zada. 2016. Performance Characteristics of High Reclaimed Asphalt Pavement Containing Bio-Modifier. Road Materials and Pavement Design. 17(3): 753-767.

[16] Ramzi, T., Galal, A., Adnan, B. \& Omar, A.-T. 1999. Evaluation of Reclaimed Asphalt Pavement Aggregate in Road Bases and Subbases. Transportation Research Record: Journal of the Transportation Research Board. 1652(1): 264-269.

[17] Peterson, G., Davison, R., Glover, C., Bullin, J. A. 2014. Effect of Composition on Asphalt Recycling Agent Performance. Transp Res Rec. 1463: 38-46.
[18] Aravind, K., and Animesh Das. 2006. Pavement Design with Central Plant Hot-mix Recycled Asphalt Mixes. Construction and Building Materials. 21 (3): 928-936.

[19] Paul, H. R. 1996. Evaluation of Recycled Projects for Performance. Proceedings of the Association of Asphalt Paving Technologists. 65: 231-254.

[20] Huang, B., Shu, X., \& Vukosavljevic, D. 2010. Laboratory Investigation of Cracking Resistance of Hot-mix Asphalt Field Mixtures Containing Screened Reclaimed Asphalt Pavement. Journal of Materials in Civil Engineering. 23(1 1): 1535-1543.

[21] Lundström, R., Di Benedetto, H. and Isacsson U. 2004. Influence of Asphalt Mixture Stiffness on Fatigue Failure. Journal of Materials in Civil Engineering. November/December: 516-525.

[22] Edil, T. B. 2011. Specifications and Recommendations for Recycled Materials Used As Unbound Base Course. University of Wisconsin-Madison,

[23] Vidal, R., Moliner, E., Martinez, G., Rubio, M. C. 2013. Life Cycle Assessment of Hot Mix Asphalt and Zeolite-based Warm Mix Asphalt with Reclaimed Asphalt Pavement. Resources, Conservation Recycling. 74: 101-14.

[24] Saeed, A. 2008. Performance-related Tests of Recycled Aggregates for Use in Unbound Pavement Layers (No. Project 4-31).

[25] Shu, X., Huang, B. 2008. Laboratory Evaluation of Fatigue Characteristics of Recycled Asphalt Mixture. Construction Build Material. 22(7): 1323-7.

[26] Mogawer, W. S., Fini, E. H., Austerman, A. J., Booshehrian, A., \& Zada, B. 2012. Performance Characteristics of High RAP Bio-modified Asphalt Mixtures. (No. 12-2411).

[27] Taha, R., Ali, G., Basma, A., and Al-Turk, O. 1999. Evaluation of Reclaimed Asphalt Pavement Aggregate in Road Bases and Subbases. Transportation Research Record: Journal of the Transportation Research Board. No. 1652. Transportation Research Board of the National Academies, Washington, DC. 264-269.

[28] Bennert, T., and Maher, A. 2005. The Development of a Performance Specification for Granular Base and Subbase Material. Rutgers University, Piscataway, NJ.

[29] Zhao, S., Huang, B., Shu, X., Jia, X., Woods, M. 2012. Laboratory Performance Evaluation of Warm Mix Asphalt Containing High Percentages of RAP. Transportation Research Record: Journal Transportation Research Board. National Academies, Washington (DC). 2294: 98105.

[30] Moghaddam, T. B., \& Baaj, H. 2016. The Use of Rejuvenating Agents in Production of Recycled Hot Mix Asphalt: A Systematic Review. Construction and Building Materials. 114: 805-816.

[31] Heidrich, O., Bird, R. N., \& Huang, Y. 2007. The Application of Recycled Waste Materials in the Construction of Asphalt Pavements. In ISWA/NVRD World Congress 2007: Challenging the Future. Newcastle University.

[32] Basic Asphalt Recycling Manual, FHWA-HIF-14-001. Asphalt Recycling and Reclaiming Association, Annapolis, MD, 2014.

[33] Hicks, R., J. Moulthrop \& Daleiden, J. 1999. Selecting a Preventive Maintenance Treatment for Flexible Pavements. Transportation Research Record: Journal of the Transportation Research Board. (1680): 1-12.

[34] Peshkin, D. G., Hoerner, T. E., \& Zimmerman, K. A. 2004. Optimal Timing of Pavement Preventive Maintenance Treatment Applications. Washington, D.C: Transportation Research Board.

[35] Milad, A., Basri, N. E. A., Borhan, M. N., \& Rahmat, R. A. A. O. 2016. A Review of Web Based Expert Systems for Flexible Pavement Maintenance. Jurnal Teknologi. 78(6).

[36] Widyatmoko, I. 2008. Mechanistic-empirical Mixture Design for Hot Mix Asphalt Pavement Recycling. Construction and Building Materials. 22(2): 77-87.

[37] Al-Qadi, I. L., Ozer, H., \& Harvey, J. (Eds.). 2017. Pavement Life-cycle Assessment. Proceedings of the 
Symposium on Life-Cycle Assessment of Pavements (Pavement LCA 2017), April 12-13, 2017, Champaign. Illinois, USA. CRC Press.

[38] https://www.wtdheattechnology.com/hot-in-placeacess $2 / 04 / 2020$.

[39] Salomon, A., \& Newcomb, D. E. 2000. Cold In-place Recycling Literature Review and Preliminary Mixture Design Procedure (No. MN/RC-2000-21).

[40] https://pw.lacounty.gov/gmed/lacroads/TreatmentCol dinPlace.aspx .access 2/04/2020.

[41] recyclinghttps://asphaltzipper.wordpress.com/2013/10/3 $0 /$ what-is-full-depth-reclamation-fdr-and-why-is-itasuperior method-of-road-patching, acess 2/04/2020

[42] Kearney, E. J., \& Huffman, J. E. 1999. Full-depth Reclamation Process. Transportation Research Record. 1684(1): 203-209.

[43] Shen, J., Amirkhanian, S., \& Aune Miller, J. 2007. Effects of Rejuvenating Agents on Superpave Mixtures Containing Reclaimed Asphalt Pavement. Journal of Materials in Civil Engineering. 19(5): 376-384.

[44] Xiao, F., Yao, S., Wang, J., Li, X. \& Amirkhanian, S. 2018. A Literature Review on Cold Recycling Technology of Asphalt Pavement. Construction and Building Materials. 180: 579-604.

[45] Murphy, D. \& Emery, J. 1997. Modified Cold In-place Asphalt Recycling. Road Construction, Rehabilittion and Maintenance. 143-150. Doi:10.3141/1545-19.

[46] Salomon, A., \& Newcomb, D. E. 2000. Cold In-place Recycling Literature Review and Preliminary Mixture Design Procedure (No. MN/RC-2000-21).

[47] O'Connell, L. 2010. Sustainable Practices and Related Performance Measures at State Highway Agencies.

[48] Apeagyei, A. K. \& Diefenderfer, B. K. 2013. Evaluation of Cold In-place and Cold Central-plant Recycling Methods Using Laboratory Testing of Field-Cored Specimens. Journal of Materials in Civil Engineering. (November): 1712-1720. Doi:10.1061/(ASCE)MT.19435533.0000717

[49] Taylor, P., Stimilli, A., Ferrotti, G., Graziani, A. \& Canestrari, F. 2013. Performance Evaluation of a Cold-recycled Mixture Containing High Percentage of Reclaimed Asphalt. Road Materials and Pavement Design. (June 2013): 37-4.

[50] Diefenderfer, B. K., Bowers, B. F., Schwartz, C. W., Farzaneh, A. \& Zhang, Z. 2016. Dynamic Modulus of Recycled Pavement Mixtures. Transportation Research Record: Journal of the Transportation Research Board. (2575): 19-26. Doi:10.3141/2575-03

[51] Cross, S. A., Kearney, E. R., Justus, H. G., \& Chesner, W. H. 2010. Cold-in-place Recycling in New York State (No. C06-21). New York State Energy Research and Development Authority.

[52] Romanoschi, S. A., Hossain, M., Gisi, A. \& Heitzman, M. 2004. Accelerated Pavement Testing Evaluation of the Structural Contribution of Full-Depth Reclamation Material Stabilized with Foamed Asphalt. Transportation Research Record Journal of the Transportation Research Board. 1896(1): 199-207.

[53] Berthelot, C. \& Gerbrandt, R. 2002. Cold In-place Recycling and Full-depth Strengthening of Clay-till Subgrade Soils Results with Cementitious Waste Products in Northern Climates. Transportation Research Record Journal of the Transportation Research Board. 1787(1): 312.

[54] Stroup-gardiner, M. 2012. Selection Guidelines for InPlace Recycling Projects. Transportation Research Record Journal of the Transportation Research Board. (2306): 3-10. Doi:10.3141/2306-01

[55] Singh, J., Singh, J. \& Duggal, A. K. 2015. A Review Paper on Reclaimed Asphalt Pavement (RAP). 454-457.

[56] Hartman, M., Turos, M., Ghosh, D., \& Marasteanu, M. 2016. Full-depth Reclamation (FDR) for Suburban/Urban and Local Roads Application.
[57] Feisthaver, B \& Lacroix, D \& Carter, Alan \& Perraton, D. 2013. Simulation and Influence of Early-life Traffic Curing for Cold In-place Recycling and Full-depth Reclamation Materials. Proceedings, Annual Conference-Canadian Society for Civil Engineering. 5: 4469-4478.

[58] Graziani, A., lafelice, C., Raschia, S., Perraton, D. \& Carter, A. 2018. A Procedure for Characterizing the Curing Process of Cold Recycled Bitumen Emulsion Mixtures. Construction and Building Materials. 173: 754762

[59] Terrel, R. L., \& Hicks, R. G. 2008. Viability of Hot In-place Recycling as a Pavement Preservation Strategy. California Pavement Preservation Center, Chico, California, Report Number: CP2C-2008-106.

[60] Gu, F., Ma, W., West, R. C., Taylor, A. J., \& Zhang, Y. 2019. Structural Performance and Sustainability Assessment of Cold Central-plant and In-place Recycled Asphalt Pavements: A Case Study. Journal Of Cleaner Production. 208: 1513-1523.

[61] Zaumanis, M., Mallick, R. B., \& Frank, R. 2014. 100\% Recycled Hot Mix Asphalt: A Review and Analysis. Resources, Conservation and Recycling. 92: 230-245.

[62] Wang, Y., Leng, Z., Li, X., \& Hu, C. 2018. Cold Recycling of Reclaimed Asphalt Pavement Towards Improved Engineering Performance. Journal of Cleaner Production. 171: 1031-1038.

[63] Hafeez, I., Ozer, H., \& Al-Qadi, I. L. 2014. Performance Characterization of Hot In-place Recycled Asphalt Mixtures. Journal of Transportation Engineering. 140(8): 04014029.

[64] Kandahl, P. S., Rao, S. S., Watson, D. E., \& Young, B. 1995 Performance of Recycled Hot Mix Asphalt Mixtures. Technical Report. National Center for Asphalt Technology (U.S.); Georgia. Dept. of Transportation.

[65] Terrel, R. L., Epps, J. A., \& Sorenson, J. B. 1997. Hot-inplace Recycling State-of-the-practice. Journal of the Association of Asphalt Paving Technologists. 66.

[66] Bemanian, S., Polish, P. \& Maurer, G. 2006. Cold In-place Recycling and Full-depth Reclamation Projects by Nevada Department of Transportation State of the Practice. (1949): 54-71.

[67] Hong, F., Chen, D.-H., and Mikhail, M. M. 2011 . Long-term Performance Evaluation of Recycled Asphalt Pavement Results from Texas. Transportation Research Record: Journal of the Transportation Research Board. 2180: 5866.

[68] Bhavsar, H., Dubey, R. \& Kelkar, V. 2016. Rehabilitation by In-situ Cold Recycling Technique Using Reclaimed Asphalt Pavement Material and Foam Bitumen at Vadodara Halol Road Project (SH 87) - A Case Study. Transportation Research Procedia. 17: 359-368. Doi:10.1016/j.trpro.2016.11.126

[69] Hu, W., Shu, X., \& Huang, B. 2019. Sustainability Innovations in Transportation Infrastructure: An Overview of the Special Volume on Sustainable Road Paving. Journal of Cleaner Production. 235: 369-377

[70] Zhao, Sheng, and Jenny Liu. 2018. Using Recycled Asphalt Pavement in Construction of Transportation Infrastructure: Alaska Experience. Journal of Cleaner Production. 177: 155-168.

[71] Lin, J. T., \& Xiao, Y. 2020. Microstructure and Performance Characteristics of Cold Recycled Asphalt Mixtures. Eco-efficient Pavement Construction Materials. Woodhead Publishing. 51-76.

[72] Torres-Machi, C., Nasir, F., Achebe, J., Saari, R., \& Tighe, S. L. 2019. Sustainability Evaluation of Pavement Technologies through Multicriteria Decision Techniques. Journal of Infrastructure Systems. 25(3): 04019023.

[73] Hafez, M., Ksaibati, K., \& Atadero, R. 2019. Pavement Maintenance Practices of Low-volume Roads and Potential Enhancement: The Regional Experience of Colorado Pavement Management System. International Journal of Pavement Engineering. 1-14. 
